\title{
$\mathrm{E}$ 급 증폭기의 바이어스 조정을 통한 LF-대역 무선 전력 전송 시스템의 수신 전력 안정화
}

\section{Received Power Regulation of LF-Band Wireless Power Transfer System Using Bias Control of Class E Amplifier}

\author{
손 용 호·한 상 규. 장 병 준 \\ Yong-Ho Son · Sang-Kyoo Han · Byung-Jun Jang \\ 요 약
}

스마트폰 무선 충전 시나리오에서는 송신 패드에 비해 수신 패드의 크기가 작으므로 수신 패드의 위치에 상 관없이 일정한 전력을 부하에 공급하는 것이 중요하다. 본 논문에서는 송신 패드와 수신 패드의 크기가 각각 $16 \mathrm{~cm} \times 18 \mathrm{~cm}$ 와 $6 \mathrm{~cm} \times 8 \mathrm{~cm}$ 의 직사각형 구조를 갖는 경우, 무선 전력 전송 송신부에 위치한 $\mathrm{E}$ 급 증폭기의 Drain 바이어스 전압만을 조정하여 수신 패드의 위치에 상관없이 일정한 전력이 부하에 공급되는 방식을 제안하였다. 설계된 LF-대역 무선 전력 시스템의 구성은 PWM IC인 TL494로 제어되는 Buck converter 구조의 전원 회로, 저 가의 IRF510 power MOSFET을 이용한 E급 증폭기, 송신 패드 및 수신 패드, 그리고 Schottky 다이오드를 이용한 풀 브릿지 정류기로 구성된다. 제작된 무선 전력 전송 시스템은 바이어스 조정을 하지 않는 경우 $240 \mathrm{kHz}$ 에서 최대 $4 \mathrm{~W}$ 출력과 $67 \%$ 이상의 시스템 효율을 가지며, 바이어스 조정을 하는 경우에는 수신 패드의 위치에 상관 없이 수신 전력을 $2 \mathrm{~W}$ 로 일정하게 유지할 수 있다.

\begin{abstract}
In wireless smart phone charging scenario, the transmitter pad is larger than the size of the receiver pad. Thus, it is important to supply a constant power to the receiver regardless of its location. In this paper, we propose a new method to regulate the receiver's power by adjusting a drain bias of class E power amplifier. The proposed LF-band wireless power transfer system is as follows: a buck converter power supply which is controlled by a pulse width modulation(PWM) IC TL494, a class E amplifier using a low cost IRF510 power MOSFET, a transmitter coil whose dimension is $16 \mathrm{~cm} \times 18 \mathrm{~cm}$, a receiver coil whose dimension is $6 \mathrm{~cm} \times 8 \mathrm{~cm}$, and a full bridge rectifier using Schottky diodes. A measured performance show a maximum output power of $4 \mathrm{~W}$ and system efficiency of $67 \%$ if we fix the bias voltage. If we adjust the bias voltage, the received power can be maintained at a constant power of $2 \mathrm{~W}$ regardless of receiver pad location.
\end{abstract}

Key words : Wireless Power Transfer, Wireless Charging, Power Regulation, Class E Amplifier, Buck Converter

$$
\text { I. 서 론 }
$$

오늘날 IT 산업을 이끌고 있는 휴대폰, 스마트폰,

\footnotetext{
「이 연구는 미래창조과학부 및 정보통신산업진흥원의 대학IT연구센터 육성지원 사업(NIPA-2013-H0301-13-2007) 및 미래부가 지원한 2013년 정보통신 · 방송(ICT) 연구개발사업의 연구 결과로 수행되었음.」

국민대학교 전자공학과(Department of Electronic Engineering, Kookmin University)

• Manuscript received May 24, 2013 ; Revised July 31, 2013 ; Accepted August 19, 2013. (ID No. 20130524-02S)

- Corresponding Author : Yong-Ho Son (e-mail : son-math@hanmail.net)
} 
테블릿 PC 등 휴대용 IT 기기는 내장된 배터리를 이 용하고 있으므로 배터리 충전이 필수적이다. 특히 배터리는 얇아지는 반면, 기기에서 요구되는 전력은 커지는 추세이므로 하루에도 한 두 번씩 휴대용 IT 기기의 충전 포트를 전선(power cable)을 통해 충전 기에 연결하여야 한다. 따라서 이러한 불편함을 없 앨 수 있는 무선 전력 전송 기술에 대한 관심이 최근 매우 높아지고 있다 ${ }^{[1]}$.

지금까지 상용화된 무선 전력 전송 기술로는 $\mathrm{LF}$ (Low Frequency) 대역 비접촉식 유도 결합(induction coupling) 방식인 WPC(Wireless Power Consortium) Qi 표준이 있다. 하지만 WPC Qi 표준은 송신 패드와 수신 패드 간의 이격 거리가 수 $\mathrm{mm}$ 로 매우 짧으며, 한 번에 하나의 기기밖에 충전할 수 없다는 단점이 있었다 ${ }^{[2]}$. 따라서 커다란 충전 패드( $25 \mathrm{~cm}$ 직경 $)$ 위에 여러 개의 수신기를 동시에 충전할 수 있는 새 로운 무선 전력 전송 기술에 대한 연구가 최근 매우 활발하다. 그 일례로 $6.78 \mathrm{MHz}$ 의 $\mathrm{HF}$ (High Frequency) 대역을 사용하는 A4WP(Alliance for Wireless Power) 표준이 최근 제안되었으나, 아직까지 별도의 주 파수로 통신 채널을 사용해야 하며, 제작 비용이 높 고, 전력 전송 효율이 낮기 때문에 상용화 단계에는 도달하지 못하고 있다 ${ }^{[3]}$. 따라서 스마트폰 무선 충전 의 활성화를 위해서는 커다란 충전 패드 위에 자유 롭게 움직일 수 있는 수신 패드를 고려하면서도, 전 력 전송 효율이 높고, 제작 비용이 저렴한 LF-대역에 서 동작하는 무선 전력 전송 시스템의 개발이 필요 하다고 판단된다. 이 경우, 수신 패드의 위치에 상관 없이 일정한 전력이 부하에 공급되는 것이 매우 중 요하다. 이에 본 논문에서는 $\mathrm{E}$ 급 증폭기로 구성된 송신부의 바이어스 전압을 가변시켜 수신 패드의 위 치에 상관없이 일정한 전력을 부하에 공급할 수 있 는 LF-대역 무선 전력 전송 시스템을 제안하였다. 제 안된 시스템은 수신 패드의 위치뿐만 아니라, 부하 의 충전 상태의 변화에도 높은 효율을 유지할 수 있 는 장점이 있다. 또한, LF-대역의 저가 소자로 설계 되어 상용화 측면에서 유리하다.

본 논문의 구성은 다음과 같다. 2장에서는 무선 전력 전송 시스템의 일반적인 구성을 소개한 후 $\mathrm{E}$ 급 증폭기, 직렬-병렬 공진기 쌍 및 풀 브릿지 구조의 정류기를 갖는 LF-대역 무선 전력 전송 시스템의 설
계 방법 및 성능을 보여준다. 3 장에서는 2장에서 설 계된 $\mathrm{E}$ 급 증폭기의 바이어스 전압을 조절할 수 있는 스위칭 모드 전원 회로를 설계하여 연동함으로써 수 신 패드의 위치에 상관없이 일정한 전력이 부하에 공급될 수 있음을 보이고, 4장에서 결론을 맺었다.

\section{LF-대역 무선 전력 전송 시스템}

\section{2-1 무선 전력 전송 시스템 개요}

WPC Qi 표준으로 알려진 LF(Low Frequency) 대 역의 무선 전력 전송 시스템의 일반적인 구성은 그 림 1 과 같다 ${ }^{[4]}$. 그림에서 알 수 있듯이 전력 전송은 송신단에서 수신단 방향인 순방향으로 공급되는 반 면, 통신 방식은 수신단에서 송신단 방향인 역방향 으로만 이루어진다. 송신단에서는 인버터 혹은 $\mathrm{E}$ 급 증폭기가 LF-대역의 고주파 신호를 발생시킨다. 발 생된 고주파는 송신공진기와 수신공진기 간의 유도 결합을 통해 수신기에 전류를 유도되고, 유도된 전 류는 정류기(rectifier)를 통해 DC 전압으로 변환되어 부하(load)로 전력을 공급한다. 이 때 충전 상태에 따 라 부하가 달라지므로 부하에 안정된 전압을 공급하 기 위하여 피드백을 통해 수신단 상태에 따라 송신 단 출력을 조정하거나 수신단에서 전압안정기(voltage regulator)를 삽입해야 한다. WPC Qi 표준에서는 LSK (Load Shift Keying) 방식으로 정보를 보내어 송 신단을 제어하는 방식과 전압안정기를 모두 사용한다. LSK 방식은 수신단에 별도의 송신 회로 없이 부하 상태만을 변경함으로써 수신단에서 송신단으로 정 보의 전달이 가능하다.

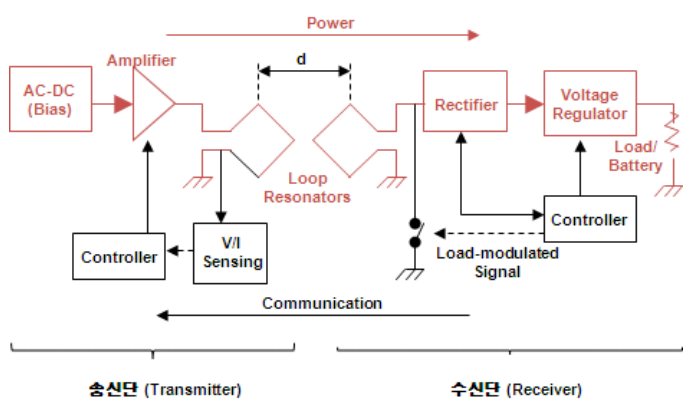

그림 1. 무선 전력 전송 시스템 구성도

Fig. 1. Configuration of a wireless power transfer system. 
WPC Qi 표준의 단점으로는 송신부 코일과 수신 부 코일이 정확히 정렬되어야만 전력 전달이 이루어 진다는 점이다. 하지만 수신 패드는 스마트폰 케이 스나 배터리 안에 삽입해야 하므로 크기가 작은 대 신 송신 패드는 크기를 키울 수 있으므로, 본 논문에 서는 기존에 $\mathrm{WPC} \mathrm{Qi} \mathrm{표준과} \mathrm{다르게} \mathrm{송신} \mathrm{패드와} \mathrm{수}$ 신 패드의 크기를 각각 $16 \mathrm{~cm} \times 18 \mathrm{~cm}$ 와 $6 \mathrm{~cm} \times 8 \mathrm{~cm}$ 의 직사각형 구조를 갖는 경우를 가정하였다. 이렇게 송신 패드에 비해 수신 패드가 작은 경우에는 수신 패드의 위치에 따라 부하에 공급되는 전력이 달라질 수 있으므로 이를 적절히 보상하는 것이 중요하다.

\section{2-2 E급 증폭기를 갖는 WPT 등가모델 해석}

본 논문에서 설계된 LF-대역 무선 전력 전송 시스 템은 $\mathrm{E}$ 급 증폭기를 기본으로 한다. Sokal이 제안한 $\mathrm{E}$ 급 증폭기의 일반적인 구성은 그림 2 와 같다 ${ }^{[5]}$.

$\mathrm{E}$ 급 증폭기는 Drain단의 전압과 전류가 동시에 겹 치지 않도록 하는 Zero Voltage Switching(ZVS) 동작 을 하므로, 이론적으로 $100 \%$ 의 전력 효율을 나타낼 수 있다. 하지만 $\mathrm{E}$ 급 증폭기의 효율은 drain 단에 직 렬로 놓여진 $L_{o u t}$ 과 $C_{o u t}$ 의 직렬 공진 회로 및 $L_{c h o k e}$ 와 $C_{\text {shunt }}$ 로 구성된 병렬 공진 회로의 주파수에 따른 기 생 저항 및 스위치의 상승 시간(rising time)과 하강 시간(falling time)의 겹침에 따라 효율이 감소하게 된 다. 보통 $\mathrm{E}$ 급 증폭기는 스위칭 동작을 위해 Gate 입 력에 일정한 duty를 갖는 구형파를 인가하게 된다. $\mathrm{E}$ 급 증폭기의 동작 원리 및 설계식은 참고문헌 [5]에 자세히 나타나 있다.

그림 2의 $\mathrm{E}$ 급 증폭기의 등가모델에 따르면 부하 저항 앞에 직렬 공진 회로가 있음을 알 수 있다. 또

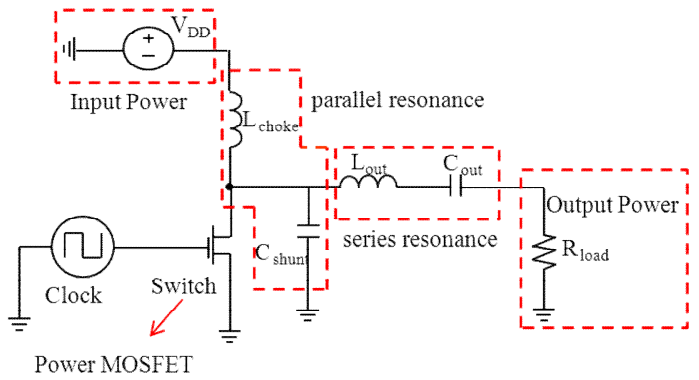

그림 2. $\mathrm{E}$ 급 증폭기의 일반적인 구성

Fig. 2. General configuration of a class $\mathrm{E}$ amplifier.

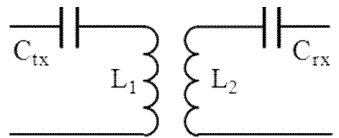

Series-Series

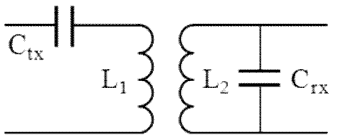

Series-Parallel

(a) 긍진기 쓰

(a) 공진기 쌍의 구성

(a) Configuration of a pair of resonators

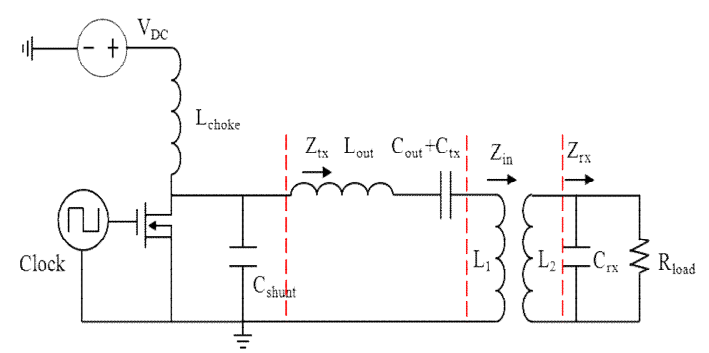

(b) 등가회로 모델

(b) Equivalent circuit model

그림 3. 직-병렬 무선 전력 전송 시스템의 등가회로

Fig. 3. Equivalent circuit model of series-parallel wireless power transfer system.

한, $\mathrm{E}$ 급 증폭기는 부하 저항의 변화에 민감하게 반 응하므로 무선 전력 전송 시스템에 별도로 설계하여 삽입하기가 어렵다. 따라서 무선 전력 전송 시스템 의 전체적인 구조를 고려하여 $\mathrm{E}$ 급 증폭기를 설계하 여야 한다. 먼저 무선 전력 전송 시스템의 공진기 쌍 의 구성은 그림 3(a)와 같이 4가지 구성이 가능하다. 부하 저항이 작을 경우에는 직렬 공진이 유리하며, 부하 저항이 클 경우에는 부하의 효과를 병렬 캐패 시터가 상쇄할 수 있는 병렬 공진이 유리하담] 이 에 본 논문에서는 $\mathrm{E}$ 급 증폭기의 직결 공진 회로를 그대로 이용할 수 있을 뿐만 아니라, 수신부 부하 저 항의 변화에 따라 $\mathrm{E}$ 급 증폭기의 성능 변화가 적도록 하기 위하여 그림 $3(\mathrm{~b})$ 와 같이 송신부에서는 직렬 공 진을, 수신부에서는 병렬 공진 방식을 사용하였다.

그림 3(b)에서 제시된 직-병렬 무선 전력 전송 시 스템의 등가회로를 해석하기 위하여 수신부 부하에 서 트랜지스터 방향으로 거꾸로 해석하면 다음과 같 다. 먼저 수신부는 $R_{\text {load }}$ 변화를 둔감하게 나타내기 위해 $C_{r x}$ 와 $R_{\text {load }}$ 가 병렬 구조를 가지므로 수신부 등 
가 임피던스는 식 (1)과 같다 ${ }^{[8]}$.

$$
\begin{aligned}
Z_{r x} & =R_{\text {load }} \| C_{r x} \\
& =\frac{R_{\text {load }}}{1+\omega^{2} C^{2} R_{\text {load }}^{2}}-j \frac{\omega C R_{\text {load }}^{2}}{1+\omega^{2} C^{2} R_{\text {load }}^{2}}
\end{aligned}
$$

식 (1)에서 볼 수 있듯이 병렬 공진 회로는 $C_{r x}$ 와 $R_{\text {load }}$ 가 직렬 공진일 때에 비해 $R_{\text {load }}$ 의 변화 폭이 분 모 $1+\omega^{2} C^{2} R_{\text {load }}^{2}$ 에 의해 작아진다. 이는 최종 설계 한 무선 전력 전송 시스템에서 $R_{\text {load }}$ 에 따라 수신 전 력 및 효율의 변화를 관찰함으로써 확인할 수 있다.

다음으로 송신단의 공진부의 $L_{1}$ 에서 바라본 등가 임피던스는 식 (2)로 주어진다. 이 때 $M$ 은 $L_{1}$ 과 $L_{2}$ 의 위치에 따른 상호 인덕턴스이다. $L_{1}$ 과 $L_{2}$ 및 $M$ 의 값 이 정해지면 $L_{1}$ 에서 바라본 $Z_{i n}$ 의 실수부와 허수부를 계산할 수 있다. $\mathrm{E}$ 급 증폭기에서 바라볼 때 $Z_{i n}$ 은 실 수부만 존재하여야 하므로 허수부 값은 시스템 효율 을 감소시키게 된다. 따라서 송신단의 토폴로지는 직렬 구조로 $Z_{i n}$ 의 허수부를 없애는 구조로 설계되어 야 한다. 또한, $\mathrm{E}$ 급 증폭기의 $C_{o u}$ 과 $C_{t x}$ 를 하나의 $C$ 로 설계할 수 있으므로 소자의 수로 줄일 수 있는 장점 이 있다.

$$
\begin{aligned}
Z_{i n}= & \frac{\omega^{2} M^{2} R_{r x}}{R_{r x}^{2}+\left(\omega L_{2}+X_{r x}\right)^{2}} \\
& +j\left(\omega L_{1}+\frac{\omega^{2} M^{2}\left(\omega L_{2}+X_{r x}\right)}{\left(\omega L_{2}+X_{r x}\right)^{2}}\right)
\end{aligned}
$$

마지막으로 식 (3)은 $C_{\text {shunt }}$ 에서 바라본 등가회로를 나타낸다. 식 (2)의 $Z_{i n}$ 과 식 (3)의 $Z_{t x}$ 를 비교하면 실 수부는 변화가 없고 허수부는 $\mathrm{E}$ 급 증폭기의 $C_{o u t}+C_{t x}$, $L_{\text {out }}$ 값에 따라 변화하는 것을 알 수 있다. 결론적으 로 무선 전력 전송 시스템 내에서 $\mathrm{E}$ 급 증폭기의 설 계는 송-수신 공진기 및 부하를 포함하면서도 $\mathrm{E}$ 급 증폭기의 ZVS 동작을 만족하도록 설계되어야 함을 알 수 있다.

$$
\begin{aligned}
Z_{t x}= & \frac{\omega^{2} M^{2} R_{r x}}{R_{r x}^{2}+\left(\omega L_{2}+X_{r x}\right)^{2}} \\
& +j\left(\omega L_{\text {out }}-\frac{1}{\omega C_{\text {out }}}+\frac{\omega^{2} M^{2}\left(\omega L_{2}+X_{r x}\right)}{\left(\omega L_{2}+X_{r x}\right)^{2}}\right)
\end{aligned}
$$

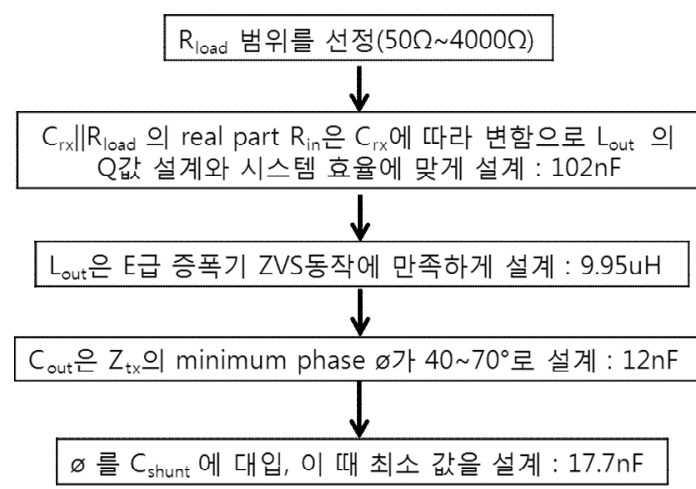

그림 4. 직-병렬 구조의 무선 전력 전송 시스템 설계 흐름도

Fig. 4. Design flow chart of series-parallel wireless power transfer system.

2-2절에서 설명한 직-병렬 공진구조를 갖는 무선 전력 전송 시스템의 설계과정은 그림 4와 같다. 설 계는 부하로부터 $\mathrm{E}$ 급 증폭기 방향으로 놓여진 소자 의 순서대로 이루어진다. 시스템 동작 주파수는 240 $\mathrm{kHz}$ 이며, 송신단 $\mathrm{DC}$ 입력은 $12 \mathrm{~V}$ 이다. 먼저, 부하 $\left(R_{\text {load }}\right)$ 의 변화는 충전 상태에 따라 가변되는 것을 고 려하였다. 식 (4-1)에서 식 (4-4)는 $\mathrm{E}$ 급 증폭기의 설 계식을 바탕으로 하였다. 먼저 식 (4-1)에서 $L_{\text {out }}$ 은 $\mathrm{E}$ 급 증폭기에서 요구하는 최소한의 $Q$ 값을 사용하면 서도 $\mathrm{E}$ 급 증폭기 동작에 적절한 값을 갖도록 하였다 [9]. 식 (4-2)로부터 $C_{o u t}$ 은 $Z_{t x}$ 의 위상(phase) 범위에서 설계되며, $\mathrm{E}$ 급 증폭기의 ZVS 동작에 만족하도록 설 계된다. 최적의 위상 값은 $65^{\circ}$ 로 설계되었다. 이 때 $Z_{i n}$ 의 실수부 값이 최대일 때가 $R_{0}$ 이다. 식 (4-3)에서 $C_{\text {shunt }}$ 는 앞에서 설계된 $L_{\text {out }}$ 과 $C_{\text {out }}$ 을 바탕으로 구한 위상 범위 내에서 설계한다 ${ }^{[10]}$.

$$
\begin{aligned}
& Q \approx \frac{\omega L_{\text {out }}}{R_{0}}, L_{\text {out }}=\omega^{-1} Q R_{0} \\
& C_{\text {out }}=\frac{\omega^{-1}}{\omega L_{1}(1-k)+R_{0}(Q+1-\sec (\theta))} \\
& C_{\text {shunt }}=\frac{2 \omega^{-1}}{\left(1+\frac{\pi^{2}}{4}\right)(1+\sec (\theta)) R_{0}} \\
& k=\sqrt{\frac{M}{L_{1} L_{2}}}
\end{aligned}
$$




\section{2-4 제작 및 측정 결과}

그림 5는 설계된 LF-대역 무선 전력 전송 시스템 의 제작 사진이다. 이 중 그림 $5(\mathrm{a})$ 는 제작된 송신 패 드 및 수신 패드를 보여준다. 수신 패드는 스마트폰 에 삽입되는 배터리의 가장자리에 코일이 감겨 있는 모양을 고려하여 구성하였으며, 송신 패드의 구성은 패드 전체에 대해 자기장이 일정하게 분포하도록 나 선형 구조로 설계하였다. 송신 패드의 자기장 분포 및 설계식은 참고문헌 [11]을 참조하여 설계하였다. 송신 패드의 크기는 $16 \mathrm{~cm} \times 18 \mathrm{~cm}$ 의 직사각형 구조 이다. 특히, 인덕터 $L_{1}$ 과 $L_{2}$ 의 기생 성분을 줄이기 위

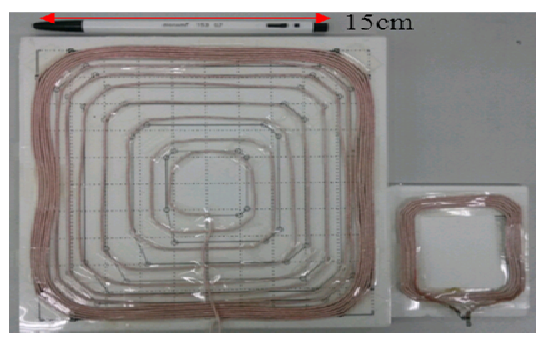

(a) 송신 패드 및 수신 패드

(a) Transmitter and receiver pads

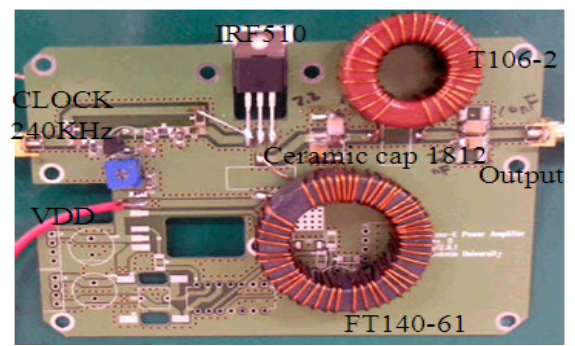

(b) $\mathrm{E}$ 급 증폭기

(b) Class E amplifier

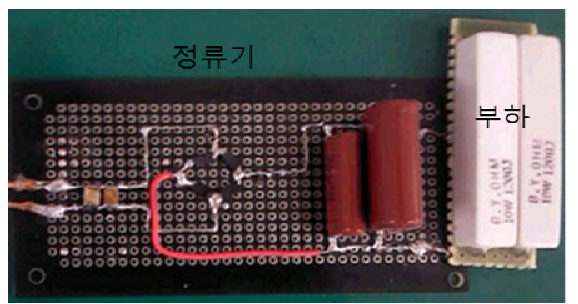

(c) 정류기 및 부하

(c) Full-bridge rectifier and load

그림 5. 설계된 LF-대역 무선 전력 전송 시스템 제작 사진

Fig. 5. Photograph of LF-band designed wireless power transfer system.
해 굵기가 얇고 가닥수가 많은 AWG Litz wire 100 - strand \#40로 제작하였다. 수신단의 크기는 $6 \mathrm{~cm} \times 8$ $\mathrm{cm}$ 로 송신 패드와 동일한 Litz wire로 설계되었다. 송신 패드와 수신 패드의 특성은 Agilent 사의 네트 워크 분석기(8753D)로 측정하였다. 측정 결과, 송신 단의 $L_{1}$ 은 $32 \mathrm{uH}$, 수신단의 $L_{2}$ 는 $3.9 \mathrm{uH}$ 값이다. 송신 패드와 수신단 사이의 거리를 $1 \mathrm{~cm}$ 로 할 경우 상호 인덕턴스 $M$ 은 공진주파수 $240 \mathrm{kHz}$ 에서 $1.65 \mathrm{uH}$ 로 측정되었다.

그림 5(b)는 송신단의 $\mathrm{E}$ 급 증폭기를 보여준다. $\mathrm{E}$ 급 증폭기의 스위치로 international rectifier사의 IRF510 Power MOSFET으로 설계되었다. E급 증폭기 직 렬 공진의 $C_{r x}$ 와 $C_{o u t}$ 는 $\mathrm{TDK}$ 사의 1812 크기의 소자 로, $L_{\text {out }}$ 은 Amidon사의 T106-2를 사용하였고, 병렬 공

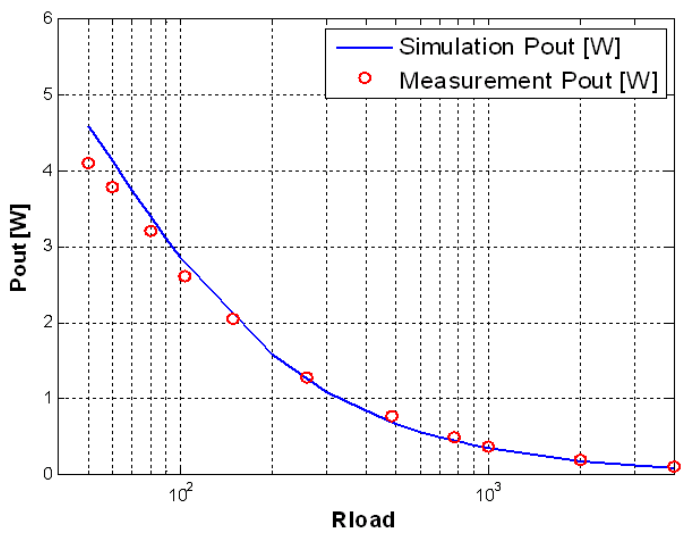

(a) $R_{\text {load }}$ 변화에 따른 출력 전력

(a) Output power by $R_{\text {load }}$ variation

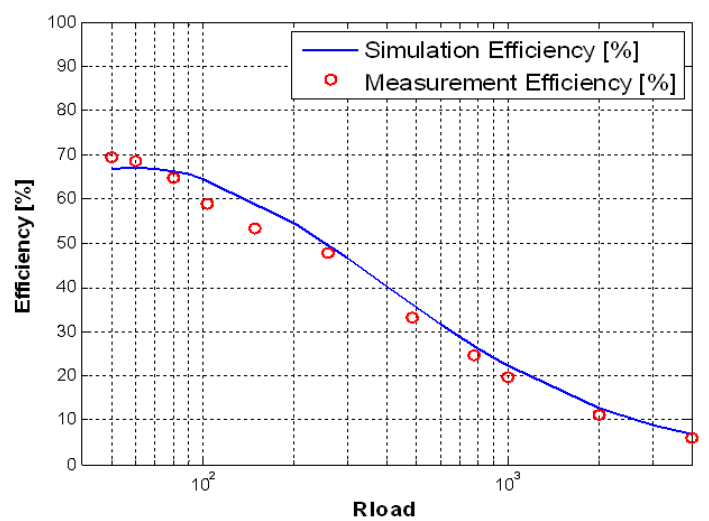

(b) $R_{\text {load }}$ 변화에 따른 효율

(b) Efficiency by $R_{\text {load }}$ variation

그림 6. LF-대역 무선 전력 전송 시스템 측정 결과 Fig. 6. Measured results of LF-band WPT system. 
진의 $L_{\text {choke }}$ 는 Amidon사의 FT140-61를 사용하였다.

그림 5(c)는 수신단은 풀 브릿지 정류기 및 벽돌 저항으로 구성된 부하를 보여준다. 풀 브릿지 정류 기는 Onsemi사의 MBRS260T3 Schottky Barrier Rectifier를 사용하였으며, 이 소자는 최적의 $\mathrm{DC}$ 변환 효 율을 얻기 위해 동작주파수에서 손실이 적은 소자로 선정하였다.

제작된 LF-대역 무선 전력 전송 시스템의 실험 결 과는 그림 6과 같다. 송신 패드 위에 놓여진 수신 패 드는 최대 전력을 수신하기 위해 송신 패드의 중심 에 위치시켰으며, 그림 5(c)의 부하 저항을 바꿔가면 서 $R_{\text {load }}$ 의 변화에 따른 수신 전력 및 효율을 측정하 였다. 입력 $\mathrm{DC}$ 전력으로 $6 \mathrm{~W}$ 를 Drain 바이어스에 공 급할 때 부하에 공급되는 전력은 최대 $4 \mathrm{~W}$ 로 $67 \%$ 의 효율을 나타냄을 확인하였다. 또한, $R_{\text {load }}$ 가 증가 함에 따라 수신 전력과 효율이 감소하기는 하지만, 수신단의 병렬 구조에 의해 그 변화폭이 크지 않음 을 알 수 있다. 예를 들어 부하 저항이 $50 \Omega$ 에서 100 $\Omega$ 으로 변하여도 출력은 $2.6 \mathrm{~W}$, 효율은 $60 \%$ 이상을 보인다. 그림에서 시뮬레이션 결과는 $\mathrm{ADS}$ 시뮬레이 션 결과로써 실험값과 유사함을 알 수 있다.

\section{III. 수신 전력 안정화 방법}

II장에서는 직-병렬 구조의 공진기와 $\mathrm{E}$ 급 증폭기 로 구현된 LF-대역 무선 전력 전송 시스템의 결과를 제시하였다. 실제 무선 충전 시나리오에서는 수신 패드의 위치가 송신 패드의 위치에 상관없이 놓여질 수 있으므로 수신 패드의 위치에 따라 수신 전력이 가변되게 된다. 따라서 수신 패드의 위치에 상관없 이 수신 전력을 일정하게 유지하기 위하여 그림 7과 같은 수신 전력 안정화 방법을 제안하였다. 그림 7 은 송신 패드 위에 수신 패드의 위치가 변할 때, 이 를 보상하기 위한 피드백 과정을 보여준다. 먼저 수 신부가 송신 패드 위에 위치하게 되면 전력 전달이 시작되며, 이 때 수신부는 부하 상태 및 부하에 공급 되는 전력의 양을 송신부로 LSK 통신 방식을 통해 피드백한다. 송신단은 이 피드백된 정보를 바탕으로 수신단에 최적인 전력을 공급하게 된다. 이를 위해 본 논문에서는 $\mathrm{E}$ 급 증폭기의 바이어스 전압을 조절 하는 방식을 사용하였다. 단, 실제 제안된 방식이 구

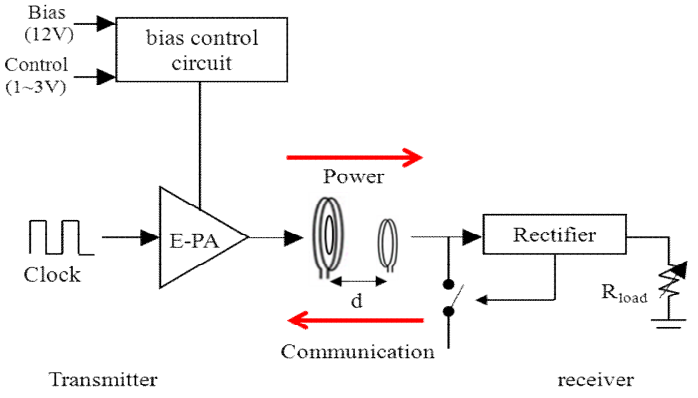

그림 7. 무선 전력 전송 시스템 수신 전력 안정화

Fig. 7. Output power regulation of wireless power transfer.

현되기 위해서는 통신부 및 제어부가 설계되어야 한 다. 하지만 본 논문에서는 $\mathrm{E}$ 급 증폭기의 바이어스 전압을 조절함으로써 수신 전력이 안정화될 수 있는 가능성을 확인하고, 이에 필요한 회로를 설계하는 것이 목적이므로, 통신부 및 제어부 없이 시스템을 설계하였다.

3-1 가변 전압을 갖는 스위칭 모드 전원 회로

$\mathrm{E}$ 급 증폭기의 Drain 바이어스 전압을 가변하기 위 해서는 마이컴 등에서 나오는 작은 제어 전압에 따 라 $\mathrm{E}$ 급 증폭기에서 요구하는 바이어스를 가변시킬 수 있는 전원 회로가 필요하다. 또한, 전원 회로에 의해서 전력 손실이 발생하면 안되므로 설계된 전원 회로는 효율이 좋은 스위칭 모드 전원 회로(SMPS: Switching Mode Power Supply)로 설계되어야 한다.

본 논문에서 설계한 가변 전압을 출력하는 스위 칭 모드 전원 회로는 그림 8(a)와 같다. PWM(Pulse Width Modulation) IC(Integrated Circuit)인 TL494의 $R_{T}$ 와 $C_{T}$ 단에 의해서 주파수 $f_{s w}$ 의 톱니파가 생성된 다. $\mathrm{IC}$ 의 피드백(FB) 단자로 입력된 전압에 따라 $\mathrm{IC}$ 는 PWM 신호를 생성한다. 생성된 TL494 PWM 신호 는 gate driver IC인 IR2109로 입력되게 되며, IR2109 소자의 출력으로 $\mathrm{HO}$ 와 $\mathrm{LO}$ 의 평형 신호가 $\mathrm{MOS} 1$ 과 $\mathrm{MOS} 2$ 에 인가된다. MOS1과 MOS2는 대칭 동작을 하게 되며, $R_{p}$ 에는 일정 $\mathrm{DC}$ 전압이 걸리게 된다. 결 론적으로 가변 전압 조정 회로는 Buck Converter 동 작을 하게 된다.

제안된 바이어스 회로의 모드 해석은 그림 $8(\mathrm{~b})$ 와 같다. 먼저 $V_{p}$ 는 식 (5-1)과 같이 입력 전압의 함수가 


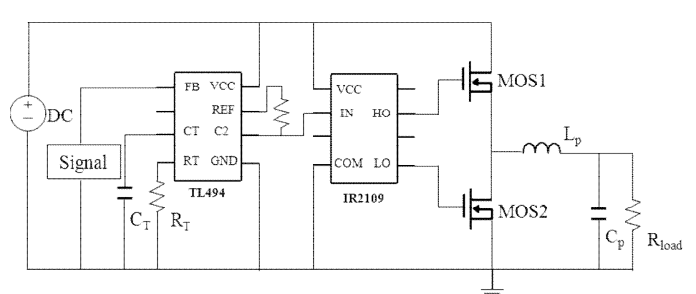

(a) 가변 전압을 갖는 전원 회로

(a) Power circuit with variable voltage

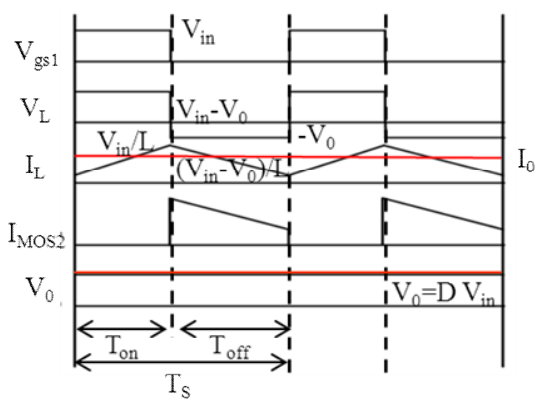

(b) 모드 해석

(b) Mode analysis

그림 8. 가변 전압을 갖는 전원 회로 및 모드 해석

Fig. 8. Power circuit with variable voltage and its mode analysis.

된다. 즉, $V_{p}$ 는 TL494의 입력 레벨에 따라 생성된 duty가 0 일 때 최소 전압 $0 \mathrm{~V}$ 에서 duty가 1 일 때 최 대전압 $V_{i n}$ 이 된다. 가변 전압 조정 회로의 설계 조건 은 입력된 전압보다 식 (5-2)와 같이 $f_{s w}$ 가 높아야 하 며, $f_{s w}$ 신호에 비해 식 (5-3)과 같이 설계된 cutoff 주 파수가 높아야 한다. 최종적으로 출력 전압을 가변 할 수 있는 전원 회로의 $R_{p}$ 전압은 $\mathrm{E}$ 급 증폭기의 Drain 바이어스 단으로 인가되어 수신 전력 안정화 를 하게 된다.

$$
\begin{aligned}
& V_{p}=D V_{i n} \\
& f_{\text {cutoff }}=\frac{1}{2 \pi \sqrt{L_{p} C_{p}}} \\
& f_{s w}=\frac{1.1}{R_{T} C_{T}}
\end{aligned}
$$

이상의 이론을 바탕으로 가변 전압을 출력하는 전원 회로를 제작하여 실험하였다. 제작된 가변 전 압 조정 회로의 출력전압을 오실로스코프로 측정하 였다. TL494 FB단으로 입력되는 전압의 레벨이 1
$3 \mathrm{~V}$ 변함에 따라 출력으로 3 19.5 V의 출력 전압이 측정되었다. $\mathrm{E}$ 급 증폭기의 설계 $V_{\text {in }}$ 전압은 $12 \mathrm{~V}$ 이 며, 가변 전압 조정 회로의 출력 전압 변화 범위를 충족한다.

\section{3-2 연동실험 및 측정}

II 장에서 제작된 $\mathrm{E}$ 급 증폭기와 3-1절의 전원 회 로를 연동한 후, 송신 패드 위 수신단의 위치에 따른 수신 전력의 변화를 측정하였다. 그림 9는 송신 패 드의 중심에서 $1 \mathrm{~cm}$ 간격으로 수신 패드의 중심을 이동하면서 수신되는 전력 및 효율을 측정한 결과이 다. 이때 수신단 부하 저항 $R_{\text {load }}$ 는 $60 \Omega$ 으로 고정하 였고, 측정된 전압은 풀 브릿지 정류기를 지나 평활 된 DC 전압을 나타낸다.

먼저, 수신 전력 안정화를 하지 않는 경우, 즉 바 이어스 전압을 $12 \mathrm{~V}$ 로 고정할 경우, 수신단의 위치 가 송신 패드 중심에서 멀어질수록 수신 전력이 낮 아지는 것을 그림 9(a)에서 확인할 수 있다. 즉, 수신 패드의 위치에 따라 유도 결합되는 자기장의 크기가 달라지므로 수신 전력 및 효율이 위치에 따라 변하 게 되며, 그 크기는 중심에서 가장 크고, 가장자리로 갈수록 작아지게 된다. 다음으로 수신 전력 안정화 를 위하여 제작된 전원 회로의 입력 피드백 전압을 수동으로 1 3 V 사이에 조정함으로써 출력 전력이 일정하게 유지할 수 있음을 확인하였다. 수신 전력 안정화를 위해 수신 전력이 가장 작을 때인 가장자 리에서의 전력을 기준으로 실험을 하였다. 가장자리 와 중심에서 일정하게 $2 \mathrm{~W}$ 의 수신 전력으로 안정화 하기 위해서는 중심에서 가장자리로 이동 시 바이어 스 변화를 $9.4 \mathrm{~V}$ 에서 $11.3 \mathrm{~V}$ 로 가변하면 된다. 이 때 효율은 큰 변화가 없음을 그림 9(b)에서 확인할 수 있다.

일반적으로 무선 전력 전송에서는 수신단에서 정 류한 DC 전압을 레귤레이터(regulator) 소자를 사용 하여 수신 전력을 일정하게 할 수 있다. 이 경우, 레 귤레이터에서 전력 손실이 발생하게 된다. 하지만 제안된 시스템에서는 송신단의 가변 전압 조정 회로 를 통해 수신단에서 레귤레이터 없이 일정 전력이 전송되도록 할 수 있으므로 레귤레이터가 필요 없는 장점이 있다. 


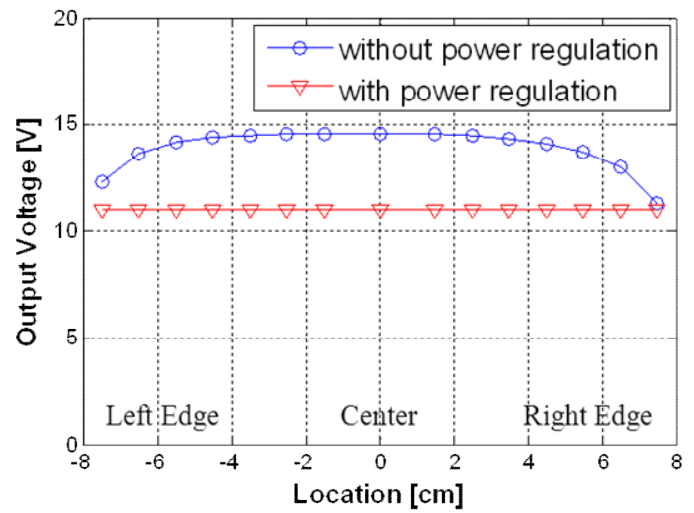

(a) 수신 전력 안정화에 따른 전력 변화

(a) Power variation output power regulation

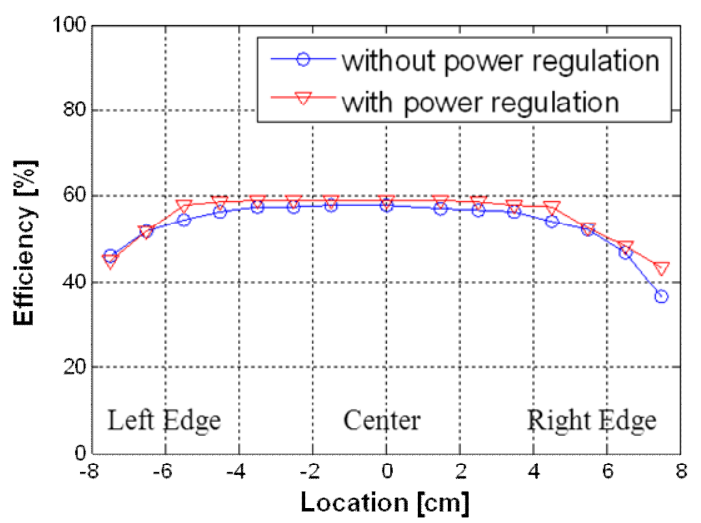

(b) 수신 전력 안정화에 따른 효율 변화

(b) Efficiency variation of output power regulation

그림 9. 수신 전력 안정화를 위한 연동실험 결과

Fig. 9. Measurement results for output power regulation.

\section{V. 결 론}

스마트폰 무선 충전의 활성화를 위해서는 커다란 충전 패드 위에 자유롭게 움직일 수 있는 수신 패드 를 고려하면서도, 전력 전송 효율이 높고, 제작 비용 이 저렴한 LF-대역에서 동작하는 무선 전력 전송 시 스템의 개발이 필요하다. 본 논문에서는 $\mathrm{E}$ 급 증폭기 로 구성된 송신부의 바이어스 전압을 가변시켜 수신 패드의 위치에 상관없이 일정한 전력을 부하에 공급 할 수 있는 LF-대역 무선 전력 전송 시스템을 제안 하였다. 제안된 시스템은 수신 패드의 위치뿐만 아 니라, 부하의 충전 상태의 변화에도 높은 효율을 유 지할 수 있는 장점이 있다. 또한, LF-대역의 저가 소
자로 설계되어 상용화 측면에서 유리하다. 본 연구 는 향후 무선 전력 전송 기술의 다양한 응용에 활용 될 수 있을 것으로 기대한다.

\section{References}

[1] 장병준, "근거리 무선 전력 전송 기술의 재고", 한 국전자파학회 전자파기술, 23(2), pp. 15-20, 2012 년 3월.

[2] Wireless Power Consortium(WPC) 홈페이지, http:// www.wirelesspowerconsortium.com

[3] Alliance for Wireless Power(A4WP) 홈페이지, http ://www.a4wp.org

[4] Byung-Jun Jang, S. Lee, and H. Yoon, "HF-band wireless power transfer system: concept, issues, and design", Progress in Electromagnetics Research, vol. 124, pp. 211-231, Jan. 2012.

[5] N. O. Sokal, A. D. Sokal, "Class E - a new class of high-efficiency tuned single ended switching power amplifier", IEEE J. Solid-State Circuits, vol. SC-10, pp. 168-176, Jun. 1975.

[6] C. Wang, G. Covic, and O. Stielau, "Power transfer capability and bifurcation phenomena of loosely coupled inductive power transfer systems", IEEE Trans. Ind. Electron., vol. 51, no. 1, pp. 148-157, Feb. 2004.

[7] J. J. Casanova, Z. N. Low, and J. Lin, "Design and optimization of a Class-E amplifier for a loosely coupled planar wireless power system", IEEE Transactions on Circuits and Systems, vol. 56, no. 11, pp. 830-834, Nov. 2009.

[8] N. Sokal, "Class-E RF power amplifiers", QEX, vol. 204, pp. 9-20, 2001.

[9] F. Raab, "Effects of circuit variations on the class E tuned power amplifier", IEEE J. Solid-State Circuits, vol. SSC-13, no. 2, pp. 239-247, Apr. 1978.

[10] J. J. Casanova, Z. N. Low, J. Lin, and R. Tseng, "Transmitting coil achieving uniform magnetic field distribution for planar wireless power transfer system", in Proc. Radio Wireless Symp., pp. 530533, 2009. 
손 용 호

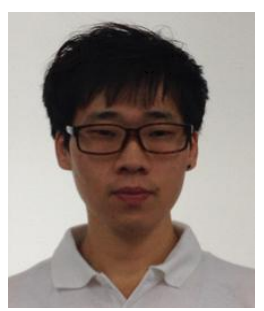

2012년 2월: 국민대학교 전자공학 과 (공학사)

2012년 3월 현재: 국민대학교 전 자공학과 석사과정

[주 관심분야] 무선통신시스템, 에 너지-IT 융합 분야
장 병 준

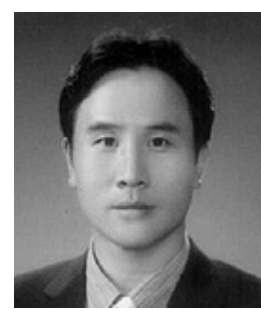

1990년 2월: 연세대학교 전자공학 과 (공학사)

1992년 2월: 연세대학교 전자공학 과 (공학석사)

1997년 2월: 연세대학교 전자공학 과 (공학박사)

1995년 3월 1999년 1월: LG전자

(주)

1999년 1월 2003년 9월: 한국전자통신연구원

2003년 10월 2005년 8월: 정보통신연구진흥원

2005년 9월 현재: 국민대학교 전자공학부 교수

[주 관심분야] $\mathrm{RF}$ /마이크로파 회로, 무선통신시스템, RF-

$\mathrm{ID} / \mathrm{USN}$, 주파수 간섭

한 상 규

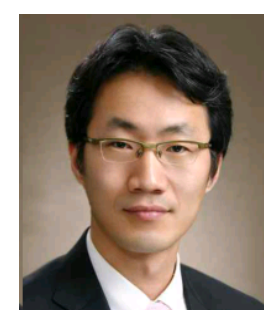

1999년 2월: 부산대학교 전기공학 과 (공학사)

2001년 2월: 한국과학기술원 전자 전산학과 (공학석사)

2005년 2월: 한구과학기술원 전자 전산학과 (공학박사)

2005년 3월 2005년 8월: 한국과학

기술원 정보전자연구소 연구원

2005년 9월 현재: 국민대학교 전자공학부 교수

[주 관심분야]전력 회로 해석 및 설계, 에너지-IT 융합 분 야 